\title{
JOURNAL.RU
}

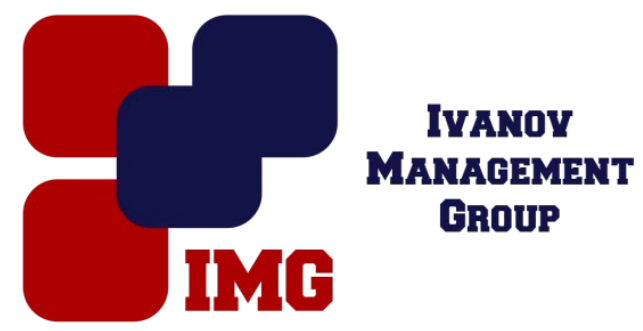

Leonova A.Z. Tyumen State University Tyumen, Russia

doi: 10.18411/lj-31-03-2017-1-03

idsp 000001:lj-31-03-2017-1-03

\section{Factors of formation of corporate commitment of personnel}

\begin{abstract}
The phenomenon of the corporate obligation works as a research object. Definition of factors of formation of the corporate obligation becomes a research objective. Researchers are mentioned in the text and their opinion is given. Authors have considered circumstances of formation of corporate commitment from various parties.

Key words: corporatecommitment, loyalty, personnel, organization.

The perspective of organizational commitment acquires the increasing relevance thanks to awareness of importance of a human factor in success and efficiency of activity of the organization today. In practical activities of the organization strengthening of commitment of personnel acts as the effective mechanism of increase in efficiency of the organization. The employee who is loyal of the company involved in activity, shows high rates of work.

We will notice how in Russia, and abroad there is no uniform understanding of commitment of personnel. In this regard there is a terminological uncertainty.

The phenomenon of corporate commitment acts as an object of a research. Definition of factors of formation of corporate commitment becomes a research objective.

The organization is interested in that the employee identified himself with it, divided the purposes and values, has been betrayed in a crisis situation. In Russianspeaking literature for the description of this phenomenon two terms - loyalty and commitment of personnel are used. Perhaps also use of the terms "devotion", "fidelity", "attachment" [Dominyak 2001: 31-35] and similar.

One of definition of the obligation, the most widespread in the western scientific literature, within the adapting approach, belongs to Lyman Porter. He defines her as "readiness of the employee to make great efforts in favor of the organization, great desire to remain in this company, acceptance of her main goals and values [Buchanan 1974: 533-546]".
\end{abstract}


On the other hand, Magura M.I. and Kurbatov M.B. define organizational commitment the psychological education including a positive assessment by the worker of the stay in the organization, intention to affect the benefit of this organization for the sake of her purposes is defined as "and to keep the membership in her. Lack of commitment is expressed in alienation of the worker from the organization" [Magura, Kurbatov 2001: 45-50]. Dominyak V.I. understands emotionally positive relation of the worker to the organization [Dominyak 2001: 31-35] as commitment.

Thus, the commitment is that integrated factor in which labor values, professional ethics of workers, their motivation and satisfaction with work are reflected. It defines expectations, features of working behavior and how personnel perceive the organization. Behind commitment there are corresponding installations defining the relation to work, to clients, to the management and to the organization in general. It is possible to select some individual characteristics of workers and organizational factors influencing degree of commitment of the organization. We will address Latfullin G. R. classification and Gromovy O.H. [Latfullin, Gromovy 2004]. Authors considered circumstances of formation of commitment from different positions in relation to the worker.

The individual characteristics of workers exerting impact on degree of their commitment of the organization:

1. motives of the choice of work (the main motive - the content of work, but not earnings);

2. motivation of work and labor values (coincidence of expectations concerning satisfaction of basic needs);

3. features of labor ethics (orientation to work as the main sphere of selfrealization, responsibility for results of the performed work);

4. education level (the education level is higher, the attachment is lower);

5. age (the person is more senior, the higher it commitment of the organization);

6. marital status (family people are more committed to the organization);

7. remoteness of the residence from the place of work (the farther, the readiness for implication of commitment is less).

The organizational factors influencing degree of commitment of the organization:

1. opportunities which are framed in the organization for satisfaction of basic needs of personnel (working conditions, compensation, opportunities for implication of responsibility and an initiative, etc.);

2. level of a working stress: in what degree work is bound to overwork, negative emotions, nervous tension;

3. degree of knowledge of workers of problems of the organization;

4. degree of an involvement into the solution of problems of the organization.

Other authors (for example, Schulz D. and Schulz S.) allocate other groups of factors of commitment to the organization:

1. enrichment of content of work;

2. autonomy of work, that is independence; 
3. variety of work;

4. positive attitude towards collective;

5. support and care of the organization of employees;

6. satisfaction with style of the management;

7. heterogeneity of personnel [Schulz 2003]. follows:

From the point of view of social installation the commitment is considered as

1. Commitment as strong desire to remain a part of the organization;

2. Commitment as desire to make the maximum efforts for the benefit of more effective functioning of the organization;

3. Commitment as conviction in corporate values and identification of a part of team [Vitman 2004: 74-82].

So, the corporate commitment, as a rule, decides as the relative force of identification of the individual on participation in this or that organization.

Conceptually, she can be characterized, at least, three factors:

1. Strong belief and acceptance of the purposes and values of the organization;

2. Readiness to make considerable efforts on behalf of the organization;

3. Strong desire to keep membership in the organization [Rebzuyev 2006: 44-59].

Formation of commitment of personnel is influenced by the following organizational sources:

1. The control system of the organization influences relationship of the worker with colleagues and the management, and also development of professional and personal qualities;

2. The personnel management system helps employees to realize and admit the place and a role to the organizations;

3. Satisfaction with working conditions depends on social policy of the organization;

4. From system of economic incentives - material satisfaction with compensation;

5. Organizational culture;

6. Personal interests of the employee.

Commitment is the integrated factor reflecting labor values, professional ethics, motivation and satisfaction with work by the employee.

In the organization it is necessary to support the high level of commitment as it is a basis of reputation of the company in the opinion of clients. Researchers agree in opinion that committed employees use all reserves and resources for achievement of the maximum results in work [Dominyak 2016: 198-203].

Thus, the commitment becomes one of the main values of the company. 


\section{Литература}

1. Vitman, D. S. (2004).Motivation and stability of personnel in the organization / D. S. Vitman. - SPb.-188 p.

2. Dominyak, V.I., (2016).Rodionova E. A. Vovlechennost of employees: motivational aspect//Global risks - local decisions: collection of materials of an annual international crossdisciplinary scientific and practical conference. Baltic institute of ecology, policy and right, Baltic institute of foreign languages and cross-cultural cooperation. On May 18, 2016, St. Petersburg / Under the general editorship of A. E. Rafe - SPb: BIEPP, BIIYaMS, Research Center ART Publishing house.-Pp. 198-203.

3. Dominyak, V. I. (2001). Various approaches to a phenomenon of loyalty and safety of the organization//Theory and practice of formation and development of school of safety (scientific, educational, methodical and organizational aspects). Collection of theses of reports of the All-Russian scientific and practical conference. - SPb.: RGPU of A. I. Herzen.Pp. 31-35.

4. Latfullin, G. R., Gromovy,O. N. (2004). Organizational behavior//Under the editorship of Latfullin G. R., Thunderous O.N. of SPb. -432 p.

5. Magura, M. I., Kurbatov, M. B. (2001). Sovremennye personnel technology//Organizational commitment//Human resource management, No. 6 (60). -Pp. 45-50.

6. Rebzuyev, B. G. (2006). Four-layer model of affective devotion of employees of the organization: experience of application on the Russian selection / B. G Rebzuyev//the Psychological magazine, No. 2. - Pp. 44-59

7. Schulz D., Schulz S. Psikhologiya and work of SPb.: St. Petersburg. -562 p.

8. Buchanan, B. (1974). Building organizational commitment: The socialization of managers in work organizations//Administrative Science Quarterly.— Vol. 19. -Pp. 533-546. 